waiting for the evidence presented to the Commission enquiring into the matter, leave alone its decision; but it is a surprise to sec you join them (Nature, 225, 486; 1970). 'This is one of the most intercsting, difficult and portentous decisions that our generation is ever likely to have to make in Britain, and your decision that "there is little to choose between one site and another", so that "in short, the airport will be best placed whero it will be least nuisance. Foulness, it would seem, is the best place" seems so superficial that a protest is surely called for, if only in the hope that more attention will be paid to some of the implications of the evidence now becoming available in time to permit a better-informed discussion at Stage $\mathrm{V}$ of the enquiry in two months' time.

First, permit me to point out that the "extra" cost of an airport at Foulness compared with the cheapest site, Cublington (discounted to 1975) is $£ 120$ million, which is surely no small matter when the greatest difference in cost of the inland sites is only $£ 9.3$ million. While this may be only 5 per cent of the total cost, personally I doubt whether it can be glossed over so easily, because it is my impression that the Commission has in many cases taken conservative estimates of the likely cost of factors difficult to estimate, such as difficulties with transport, preparation of the site, meteorology, and air safety; and with the exception of meteorology, on present showing most of these unknowns are likely to be most important at Foulness, so that the most serious risk of underestimated costs occurs there. There is already ample experience of construction and operational problems inland, but it is quite possible that our hopeful entrepreneurs will encounter a whole new dimension of unforeseen expense as they start to construct transport facilities out through the East End of London to build runways among the shifting sands and sea fogs of the North Sea. And it will not be they, but the taxpayer, who receives the bill.

Second, while you abuse the devoted and ( $\mathrm{I}$ would have thought) generally rather efficient civil servants, who have made our existing international airports tho busiest and most successful ones outside North America, with none of the major transport problems that beset the larger ones there, for ignoring wider aspects of the decision where to site the Third London Airport in favour of the choice which they know to be safe, may I point out some other wider implications which you in your turn do not mention? The question of the nuisance value of the airport to which you attach prime importanco is of only local, not even regional, interest, but the establishment of a major, well appointed, conveniently sited airport in the near future to take overflow traffic from our existing airports is a matter of national importance if we are to compete for the transatlantic tourist trade with foreign centres such as Paris, and facilitato the smooth growth of air freight services in the interests of the need to increase exports. If thore is any question of undue delay or difficulty of access to the new airport as a result of a decision to minimize its local nuisance value in the way you suggest, the cost to the country could be very serious in terms not just of a little local noise but as an influence on our total balance of trade.

Third, while national considerations surely ought to take precedence over local ones, there are also some local considorations that have received curiously little comment. It would appear from the commission's calculations that they anticipate that if the Third London Airport is built inland it will be ready fairly sonn and will result in the closure of a wholo series of other nuisances such as Luton Airport and various military airfields, and will attract business away from moro distant sites such as Birmingham and Manchester airports, so that while a major new nuisance will be created in a tract of countryside apparently specially chosen because its remoteness will minimize the effect, other nuisances aro liable to be reduced over a wide area round about. Judging by recent protests in the Press, the closure of Iuton airport alone will cause more alleviation of local discontent than will ever be provoked by the utmost development of any of the other inland airport sites currently under consideration for development. On the other hand, the Commission appears to anticipate that if the new airport is sited at Foulness, both Luton and Gatwick airports may have to be developed to take overflow traffic while it is being constructed, whilo much traffic from the Midlands, which might have gone to an inland Third London Airport, will be diverted to Birmingham and Manchester instead. If so, Foulness will miss much of the business that might have been expected inland, which will be diverted to not just one but four or more other proliferating sources of local nuisance instead, leaving an expensive white elephant stranded in idleness on the Thames mudflats.

There are several other matters which one could raise, such as what will happen to Southend and north Kent if it turns out that Noise and Number Indices are among the variables that have been underestimated; but I have added too much to the verbiage being lavished on this issue already. Basically, I would like to suggest that whereas it is possibly arguable that the original decision to select Stansted was perhaps based on too narrow grounds of oporational convenience, even now the level at which you argue the decision should bo taken, local nuisance value on a regional basis, is still too narrow. The moment that it is enlarged further to a national scale, in terms of the facilitation of trade, and the alternatives of the dispersal of traffic to many sites, each of which becomes a growing local nuisance itself, or concentration at a single central site, deliberately placed where it will cause least nuisance, with the minimum difficulties of construction, and close to existing transport facilities, then an inland site must win.

$$
\text { Yours faithfully, }
$$

62 Vicarage Road,

$$
\text { W. R. P. BOURNE }
$$

Watford,

Hertfordshire.

\section{Goldfinger no Longer}

SIR,-I wish to associate myself with the views of R. S. Glover (Nature, 225, 570; February 7, 1970) and in particular his comments on the rolationship between field data, the analysis of natural fluctuations and the study of marine pollution. To the number of points which, as he says, are self-evident, I would like to add another that cannot be over-emphasized but does not yet appear to have been appreciated: the quantitative data relating to complex ecosystems will be obtained only by the simultancous deployment of experienced personnel on a scale and for a duration that would be new to environmental research in this country. The one man/one species approach, forced on so many biologists by circumstances beyond their control and which has nonetheless contributed so much to our knowledge of marine biology, must now bo supplemented by the multi-disciplinary, largeteam approach if the dynamics of natural populations aro to be recorded, analysed and understood. As one who has tricd with limited means to move into this more complex sphere, I am obliged to concede that the majority of marine biologists, working as we do in coastal universities as small units with or without a few research students, can achieve neither the continuity nor the brcadth essential for this type of study. Collaboration between people with complementary or similar interests who also happen to be close neighbours affords a partial remedy, but the nature of the subject makes it preeminently ono for research institutes or other major units.

Your doubts about routine data collection ranking as research must surely stem not from failure to see the relevance to population dynamics, but perhaps from a belief that natural fluctuations are wo woll documented 
and understood already that we need routine observations solely to set against established base-lines. Nothing could be further from the truth. For a variety of reasons, not least the scale of effort required and the pursuit in recent decades of more fashionable fields or quick results, we know very little about the extent and causes of natural fluctuations. Nor are we within sight of being able to predict the probable biological repercussions of the elimination or weakening (through pollutants) of one or two "key" species in marine communities. A massive new programme of fundamental research is required to establish the base-lines of natural variation, and its essential basal requirement is routine, long-term field observation and measurement. The point where such activity becomes "routine" in the perjorative sense and contributes little to research is far distant.

If, however, base-line studies are seen as merely the collection of numerical data at particular sites in anticipation of a possible pollution incident, and if such data are not used to further our understanding of natural variation, you are correct to feel that this activity does not qualify as research. If it is considered necessary, and this I doubt in most cases, the problems of who does it and finances it have yet to be faced; but it seems most unlikely that universities will accept it as a just demand on their limited research time and facilities.

Yours faithfully,

J. R. LEwIS

Wellcome Marine Laboratory,

Robin Hood's Bay,

Yorkshire.

\section{Sir William Grove}

SiR,--In your issue of January 24, 1970, there appeared an extract from Nature of 100 years ago consisting of a letter from Sir W. R. Grove concerning the correlation of physical forces. The following footnote to the letter was appended: From a letter to the Editor, Nature, 1, 335, January 27, 1870. Grove was the first to demonstrate the electrolytic decomposition of water.

The Dictionary of National Biography gives the dates of birth and death of Sir W. R. Grove as July 11, 1811, and August 1, 1896, respectively. If these particulars are correct, Sir W. R. Grove could hardly have been the first to demonstrate the electrolyte decomposition of water, as the first mention of this having been accomplished was in Nicholson's Journal, 4, 183 (1800), which was an account of experiments done by W. Nicholson and Sir A. Carlisle.

\section{Yours faithfully,}

SydNEy GILI

University of Manchester

Institute of Science and Technology.

\section{The Social Sciences}

SiR,--In "Miscellaneous Intelligence" for January 31 (Nature, 224,$405 ; 1970$ ) you state: "if any of the social sciences is a science, social anthropology is, ...". A more preposterous statement is difficult to imagine. Surely that must have been written by one of the visionary prophets of the sect. It is not rigour that is exhibited by the long period of introspection between field work and publication, but an inability to apply anything like scientific method to the materials. I think you owe an apology to anthropological linguists, physical anthropologists, and archaeologists, who exhibit some measure of the rigour of science and its methods.

$$
\begin{aligned}
& \text { Yours faithfully, } \\
& \text { JoHN BUETTNER-J ANUSCH }
\end{aligned}
$$

Duke University Medical Center,

Durham,

North Carolina.

\section{British Diary}

\section{Monday, February 23}

Genius in Science (5 p.m.) Professor Michael Polanyi, London Sichool of Economics and Political Science, at Houghton Street, Aldwych, London WC2. Modern Mixing Systems $(6.45$ p.m.) Mr P. Whitaker, Institution of the

Terminal Units and Transmission in Electronic Telephone Exchanges (5.30 p.m.) Mr T. H. Flowers, Institution of Electrical Engineers, at $(5.30 \mathrm{p} . \mathrm{m}$.$) Mr T. H. Flowe$
Savoy Place, London WC2.

The Mechanical Equipment for the Construction of the Victoria Line (6 p.m. discussion) Institution of Mechanical Engineers, at 1 Birdcage Walk, London SW1.

Thermoplastics in the Cable Industry $(7.30 \mathrm{p.m}.) \mathrm{Mr} \mathrm{R}$. H. Greenhalgh, Plastics Institute, at the Stork Hotel, Queen Square, Liverpool.

Tuesday, February 24

Design of Pressure Vessel Components (all-day discussion) Institution of Mechanical Engineers, at 1 Birdcage Walk, London SW1.

Electrolyte Movements within the Colon (5.30 p.m.) Professor O. M. Wrong, University of London, at the Institute of Child Health, 30 Guilford Street, London WC1. (Fourteenth of fifteen lectures on "The Scientific Basis of Medicine".)

Excavations at Swanscombe 1968-69 (5.45 p.m.) Dr J. Waechter, University of London, at the Institute of Archaeology, 31-34 Gordon Square, London WC1.

Some New Concepts in Polymer Stabilization (6 p.m.) Professor G. Scott, Society of Chemical Industry, Plastics and Polymer Group, at 14 Society of Chemical Industry,
Belgrave Square, London SW1.

The Content of Measurements Courses for Electrical Engineers (5.30 p.m. discussion) Institution of Electrical Engineers, at Savoy Place, London WC2.

Yorkshire's Pink Gold-Its Discovery, Exploitation and Evaluation, Mr L. S. Phillips; The Analysis of Crude Potash Materials, Dr J. M. Skinner (8 p.m.) Society for Analytical Chemistry; and the Borough Road, Middlesbrough.

Wednesday, February 25

Hi-Fi (6.30 p.m.) Mr J. Moir, Institution of Electrical Engineers, at King Edward VI Grammar School, Chelmsford.

Investigation into the Permeametry and Crystal Structure of Fats and Fat Blends, Mr G. C. Evans; The Use of Low Resolution NMR for the Rapid Determination of Solids Content of Fat Blends, at 14 Belgrave Square, London SW1.

Kinetics and Regulation of Erythropoiesis (2 p.m.) Dr L. G. Lajtha University of London, at the Royal Postgraduate Medical School, Du Cane Road, London W12.

Low Light Television Tubes (6 p.m.) Dr P. L. Batey, Institution of Electronic and Radio Engineers, at 9 Bedford Square, London WC1.

Man, Mind and Machine (1.10 p.m.) Professor Philip M'Pherson, City University, at the Graduate Business Centre, Gresham College, Basinghall sity, at the Graduate

Maps as a Medium of Scientific Information (1 p.m.) Royal Institution, History of Science Discussion Group, at 21 Albemarle Street, London W1

Newer Techniques of Thermal Analysis with special reference to Calorimetry (2.30 p.m.) Society for Analytical Chemistry; and the Chemical Society, in the Department of Chemistry, University of Keele, Staffs.

Stereophonic Transmission $(7.30$ p.m.) Dr G. J. Phillips, Institution of Electrical Engineers, at the Star and Garter Hotel, Dorking, Surrey. Sterilizable Plastics Packaging for Foodstutrs (10.30 a.m. symposium)
Society of Chemical Industry, in the Meeting Room of the Zoological Society of London, Regent's Park, London NW1.

The Application of Test Results to the Calculation of Short-circuit Levels in Large Industrial Systems with Concentrated Induction Motor Loads (5.30 p.m.) Mr C. B. Cooper, Dr D. M. McLean and London WC2.

The Direct Determination of Oxygen in Organic Compounds (6.30 p.m.) Mr P. Gouverneur, Society for Analytical Chemistry, at the Leicester Lounge, Glasshouse Street, London W1.

The Interaction of Power Supply Systems and Digital Equipment in Aircraft (6 p.m. discussion) IEE/RAeS, London Joint Group, at the Royal Aeronautical Society, 4 Hamilton Place, London W1.

The Neuropharmacology of Sleep (5.30 p.m.) Professor M. Jouvet (Lyon), University of London, at Charing Cross Hospital Medical School, Chandos Place, London WC2.

Trends in Diffusion (two-day conference) Institute of Physics and the Physical Society; The Institute of Metals; and the National Physical Laboratory, at the NPL, Teddington, Middlesex.

\section{Thursday, February 26}

Ammonium Nitrate Production $(6.30$ p.m. $)$ Mr R. Carter, Institution of Chemical Engineers, at I.C.I., Ltd, Billingham.

Architectural Aerodynamics ( 9.30 a.m., two-day meeting) Royal Society, at 6 Carlton House Terrace, London SW1.

Medical Problems of Cold Immersion (5.30 p.m.) Dr W. R. Keatinge, University of London, at the Institute of Child Health, 30 Guilford Street, London WC1. 